\title{
Status of birth and pregnancy outcome capture in Health Demographic Surveillance Sites in 13 countries
}

\author{
Peter Waiswa ${ }^{1,2,11} \cdot$ Joseph Akuze ${ }^{1,2,4}$ (D) $\cdot$ Cheryl Moyer ${ }^{1,3} \cdot$ Doris Kwesiga $^{1,2} \cdot$ Samuelina Arthur $^{1} \cdot$ \\ Osman Sankoh ${ }^{1,5,6,7} \cdot$ Paul Welaga $^{1,10} \cdot$ Martin Bangha $^{1,9} \cdot$ Jacques Eminas $^{1} \cdot$ Sheru Muuo $^{1}$ • \\ Abdhalah Ziraba ${ }^{1,9} \cdot$ Kate Kerber ${ }^{1,8} \cdot$ INDEPTH Network MNCH team
}

Received: 9 November 2017/Revised: 17 February 2019/Accepted: 28 March 2019/ Published online: 26 June 2019

(C) The Author(s) 2019

\begin{abstract}
Objectives We compared pregnancy identification methods and outcome capture across 31 Health Demographic Surveillance System (HDSS) sites in 14 countries in sub-Saharan Africa and Asia.

Methods From 2009 to 2014, details on the sites and surveillance systems including frequency of update rounds, characteristics of enumerators and interviewers, acceptable respondents were collected and compared across sites.

Results The 31 HDSS had a combined population of over 2,905,602 with 165,820 births for the period. Stillbirth rate ranged from 1.9 to 42.6 deaths per 1000 total births and the neonatal mortality rate from 2.6 to 41.6 per 1000 live births. Three quarters $(75.3 \%)$ of recorded neonatal deaths occurred in the first week of life. The proportion of infant deaths that occurred in the neonatal period ranged from 8 to $83 \%$, with a median of 53\%. Sites that registered pregnancies upon locating a live baby in the routine household surveillance round had lower recorded mortality rates.

Conclusions Increased attention and standardization of pregnancy surveillance and the time of birth will improve data collection and provide platforms for evaluations and availability of data for decision-making with implications for national planning.
\end{abstract}

Keywords INDEPTH Network · Maternal Newborn Child Health Working Group · Stillbirth · Neonatal · Mortality $\cdot$ Perinatal mortality $\cdot$ Demographic Surveillance Sites

\section{Introduction}

Kate Kerber: Senior author.

Peter Waiswa and Joseph Akuze are joint first authors.

Electronic supplementary material The online version of this article (https://doi.org/10.1007/s00038-019-01241-0) contains supplementary material, which is available to authorized users.

Joseph Akuze

joseph.waiswa@1shtm.ac.uk; jakuze@musph.ac.ug

1 INDEPTH Network Maternal Newborn and Child Health Working Group, Kampala, Uganda

2 Department of Health Policy Planning and Management, Karolinska Institutet, Kampala, Uganda

3 University of Michigan, Ann Arbor, USA

4 Department of Epidemiology and Population Health, London School of Hygiene and Tropical Medicine, London, UK

5 Statistics Sierra Leone, Tower Hill, Freetown, Sierra Leone
At the end of the Millennium Development Goals (MDGs) era, the number of children dying each year before the age of five dropped by $54 \%$, from an estimated 12.7 million in 1990 to fewer than six million in 2015. In addition, a 44\% reduction in maternal mortality ratio (MMR), from 385 per

6 College of Medicine and Allied Health Sciences, University of Sierra Leone, Freetown, Sierra Leone

7 School of Public Health, Faculty of Health Sciences, University of the Witwatersrand, Johannesburg, South Africa

8 University of Alberta, Edmonton, Canada

9 African Population and Health Research Centre, Nairobi, Kenya

10 Navrongo Health Research Centre, Navrongo, Ghana

11 Global Health Division, Karolinska Institutet, Solna, Sweden 
100,000 live births in 1990 , to 216 per 100,000 live births in 2015 was seen. Despite great progress in reducing child deaths during the MDGs, neonatal mortality had the least progress and now accounts for $44 \%$ of these deaths globally (UNICEF et al. 2015). An estimated 2.6 million newborns die each year (IGME 2017), whereas 2.6 million babies stillborn (Blencowe et al. 2016). Furthermore, the burden of disability and ill health arising out of the neonatal period is substantial. Neonatal conditions accounted for 202 million disability-adjusted life years in 2010 , or $8.1 \%$ of the worldwide total (Murray et al. 2012). The risk of death is highest during the birth process and the days immediately after, across all countries and income levels. Approximately $36 \%$ of neonatal deaths occur on the first day and $73 \%$ in the first week after birth (Oza et al. 2014). The progress in stillbirths was even less, with an estimated decline from 24.7 stillbirths per 1000 total births in 1990 to 18.4 stillbirths per 1000 total births in 2015, a $2 \%$ annual reduction rate (de Bernis et al. 2016; Lawn et al. 2016).

The Sustainable Development Goals (SDGs) which were launched in 2016 set ambitious targets to be achieved by 2030. Goal 3 of the SDGs focuses on health, and its vision is "to ensure healthy lives and promote wellbeing for all at all ages". The SDGs target a MMR of less than 70 deaths per 100,000 live births globally or not more than 140 deaths per 100,000 live births for any county by 2030 . The under-five mortality target is 25 deaths per 1000 live births by 2030 (UN 2015). The targets set in the SDGs and their accompanying strategies are ambitious; however, to achieve them we require improved, timely metrics, but also innovation and policies based on local evidence, especially in low- and middle-income countries. Mortality must be measured in order to guide the achievement of the Every Newborn Action Plan (ENAP) vision to end preventable newborn mortality and stillbirths, to determine whether the goals have been met, to monitor coverage of interventions and to ensure rapid feedback to evaluate whether the interventions are reaching those in need, especially populations at risk. To this end, the 5-year multipartner ENAP Measurement Improvement Roadmap details steps to meet the key ENAP milestones, including better coverage and quality of birth and death information, with improvements in data collection tools for measuring mortality outcomes like neonatal mortality rates (NMR) and stillbirth rates (SBR) (Moxon et al. 2015).

Despite this increasing attention to stillbirths (Froen et al. 2016) and neonatal deaths(Shiffman 2010), little longitudinal information is gathered on these deaths and their surrounding circumstances in low- and middle-income countries (LMIC). The burden of stillbirths and neonatal deaths is greatest where local data for planning and action are neither readily available nor accurate. Few large-scale studies that document perinatal outcomes exist in a community setting (Engmann et al. 2012).

The International Network for the Demographic Evaluation of Populations and their Health (INDEPTH) operates in these high-burden settings, through an affiliated group of Health and Demographic Surveillance Systems (HDSS) sites. These sites monitor demographic, social, health and other characteristics of target populations. Founded in 1998, by December 2015 it had brought together 49 HDSS field sites from 43 member research centres in 20 countries (INDEPTH Network). Member sites collect data on various indicators (Sankoh and Byass 2012).

The ongoing surveillance in INDEPTH sites makes them valuable resources for improving the understanding of birth outcomes in the LMICs. Their longitudinal nature positions them as a great platform for assessing the lifecycle changes from pregnancy until death. We examined available data and compared pregnancy identification and outcome capture across INDEPTH Network HDSS sites in 13 countries in sub-Saharan Africa and Asia. By doing so, we aim to contribute to improving methods for identifying pregnancies and capturing their outcomes at the population level, a key ENAP requirement.

\section{Methods}

\section{Data collection and management}

All INDEPTH member sites were invited to participate in the INDEPTH Network Maternal, Newborn and Child Health Working Group (MNCH_WG) activities within the INDEPTH Network because the network membership criteria require all sites to collect data on pregnancy and their outcomes and also to conduct maternal and newborn causes of deaths using verbal autopsy. However, participation is not mandatory because it depends on HDSS sites' interests and the nature of their core research activities. The data for this analysis were solicited from all INDEPTH Network member HDSS sites using a standard template sent out to teams to complete. This request was sent by the INDEPTH Network secretariat hosted in Accra, Ghana, to all the 48 INDEPTH Network member sites at the time and not only to the MNCH_WG member sites. Of 48 sites contacted, 31 responded and returned the data request template to the secretariat. One site had not yet been added to the INDEPTH membership at the time of data collection. Sites were asked to submit 2009-2014 data on the crude population numbers; number of pregnancies; the pregnancy outcomes including live birth, stillbirth, neonatal death and timing of death; details of the birth, including gestational age, delivery location; and background characteristics, including age of mother, mother's education, household 
Table 1 Outcome definitions. Source: Moxon et al. (2015) (9)

\begin{tabular}{|c|c|c|}
\hline Indicator & Numerator & Denominator \\
\hline Stillbirth rate & $\begin{array}{l}\text { International comparison definition: number of babies born per year with no signs of life } \\
\text { weighing at least } 1000 \mathrm{~g} \text { and after } 27 \text { completed weeks of gestation or more than } 35 \mathrm{~cm} \\
\text { ICD-10 definition: number of babies born per year with no signs of life weighing at least } 500 \mathrm{~g} \\
\text { and } \geq 22 \text { weeks completed weeks of gestation }\end{array}$ & $\begin{array}{l}1000 \text { total (live and } \\
\text { stillborn) births }\end{array}$ \\
\hline $\begin{array}{l}\text { Neonatal mortality } \\
\text { rate }\end{array}$ & Number of live born infants per year dying before 28 days of life ( $0-27$ days) & 1000 live births \\
\hline $\begin{array}{l}\text { Early neonatal } \\
\text { mortality rate }\end{array}$ & Number of live born infants per year dying before 7 days of life (0-6 days) & 1000 live births \\
\hline $\begin{array}{l}\text { Infant mortality } \\
\text { rate }\end{array}$ & Number of infants per year dying before 12 months of life ( 365 days) & 1000 live births \\
\hline
\end{tabular}

Definitions of outcomes used in the study 2009-2014. ICD-10: International Classification of Diseases version 10; CRVS: civil registration and vital statistics; HMIS: health management information system

wealth index. However, majority of the sites did not provide the detailed data on the births and the background characteristics of the mother; therefore, these data are not presented in this paper for consistency. The data that the sites provided were collected by each HDSS as a part of their routine monitoring and surveillance. Because of data ownership issues, a protocol was sent to the HDSS site teams to guide them to analysing their own datasets and enter the data in a standardized, structured Excel forms which were then shared with the research team via webmail. The outcome definitions used in this paper are detailed in Table 1.

The details on the HDSS context and the characteristics of the surveillance rounds including the frequency of surveillance updates, the characteristics of interviewers and acceptable respondents were also collected through a review of the HDSS profiles and published manuscripts on the INDEPTH Network website; we collated these and compared across sites. All data received via the Excel templates and the reviews on the HDSS profiles were compiled and analysed by the lead author team. Site representatives and maternal newborn focal persons were sent the draft manuscript via email to review their data that were compiled by the author team; this was followed up with a meeting and discussions about the data during workshops in Kampala in June 2015 and in Addis Ababa in November 2015. After the face-to-face meetings and discussions, the HDSS site were sent updates and revisions made in June 2016.

\section{Data analysis}

The data were analysed using Stata/SE 14 and MS Excel software. Descriptive analyses were conducted to describe the birth and mortality profile across sites.

Stillbirth rates, early, late and overall NMR and infant mortality rates were calculated using the raw data provided by the sites and averaged over the 5-year data available.
They were compared to national and regional estimates available from other sources including global estimates and large-scale household surveys. The ratio of stillbirths to neonatal deaths and the proportion of infant deaths that occurred during the neonatal period were calculated, and we compared the stillbirth rates and NMR to national and global averages. The stillbirth rates, early and overall NMR and infant mortality rates of seven sites were excluded or not shown because either they did not provide data on neonatal deaths or the neonatal mortality rates computed were less than 10 deaths per 1000 live births-a cut point that we set for what could be considered realistic mortality rates given the low-resource settings of INDEPTH HDSS.

\section{Results}

Out of the 48 sites that were contacted, 31 sites replied (65\% response rate). Data from the 17 sites that did not respond are not included in this analysis, but characteristics of all 48 sites are included in Supplementary table 2. The 31 sites that submitted data were located in thirteen countries, representing three major regions (Central and South Asia, sub-Saharan Africa and Eastern and Southeastern Asia). Although data for the period of interest were from the years 2009 to 2014, the latest data for the 31 sites submitted varied from 2010 to 2014, with $3 \%$ from 2010, $32 \%$ from 2011, 26\% from 2012, 16\% from 2013 and 23\% from 2014. The 31 sites had a combined population of over 2.9 million, with 165,720 births recorded in 2014 for the period 2009-2014. Their population ranged from 20,630 to 268,783 and their size from 135 to 7162 square kilometres.

\section{Stillbirths}

The sites had differential capacity in measuring different rates. Stillbirth rates ranged from 7 deaths per 1000 total births, to 42.6 deaths per 1000 total births, with a median 
stillbirth rate of 17 per 1000 total births across sites (Supplementary table 3). The ratio of SBR to NMR ranged from 0.3 to 1.6 , with a median ratio of 0.75 (Fig. 1 and Supplementary table 3). Most sites only collected the most basic information on stillbirths and did not collect data on whether or not the stillbirth occurred in the intrapartum or antepartum period or appeared fresh or macerated at delivery. Out of 24 sites presented in Supplementary table 3, 23 sites had data on stillbirths. Of the 23 sites with stillbirth data, 19 HDSS sites had a 5-year average stillbirth rate that was lower than national estimates for 2015 (Supplementary table 3).

\section{Neonatal deaths}

Among the 31 sites, 28 submitted data on the number of neonatal deaths and the age of the newborn at the time of death. Of these 28 sites, four sites had an NMR that was less than 10 deaths per 1000 live births. These unrealistically low rates were excluded. The NMR in the remaining 24 sites ranged from 11 deaths per 1000 live births to 41.6 deaths per 1000 live births, with a median NMR of 21.4 across sites and a median early NMR (a death in the first 7 days after birth) of 14.2 (Supplementary table 3). The proportion of all neonatal deaths that occurred during the first week was $71.4 \%$ across sites. The proportion of infant deaths (first year deaths) that occurred during the neonatal period ranged from 22.6 to $100 \%$, with a median of $55.1 \%$ across sites (Fig. 2 and Supplementary table 2). Out of 24 sites with data, neonatal deaths or neonatal mortality greater than 10 deaths per 1000 births, 15 HDSS sites had a 5-year average NMR which were lower than national estimates of NMR for 2014 (Supplementary table 3).

\section{Surveillance characteristics}

Table 2 highlights surveillance processes in sites. Fifteen sites had more frequent surveillance rounds, ranging from monthly to quarterly rounds. The other sixteen sites with infrequent rounds conducted them either once or twice a year. The majority of the sites collect data relevant to birth outcomes including maternity history, pregnancy and outcome surveillance, child health, verbal autopsies, reproductive health, immunization, among others. Seven sites asked questions directly to women of childbearing age in the household, while 15 asked any adult respondent present in the home, not necessarily a woman. Seventeen sites registered pregnancies upon locating a live baby in the routine household surveillance round or through community notifiers. Of the 31 sites, 18 collected data using a paper-based system and this was then entered into a database, while 8 used electronics-based data collection. Most of the sites stored their entered data in either an SQL or DBASE or Open Household Registry systems.

\section{Comparison to national and regional rates}

While national and sub-national CRVS and HMIS systems are being strengthened, most countries with INDEPTH HDSS sites rely on five-yearly Demographic and Health

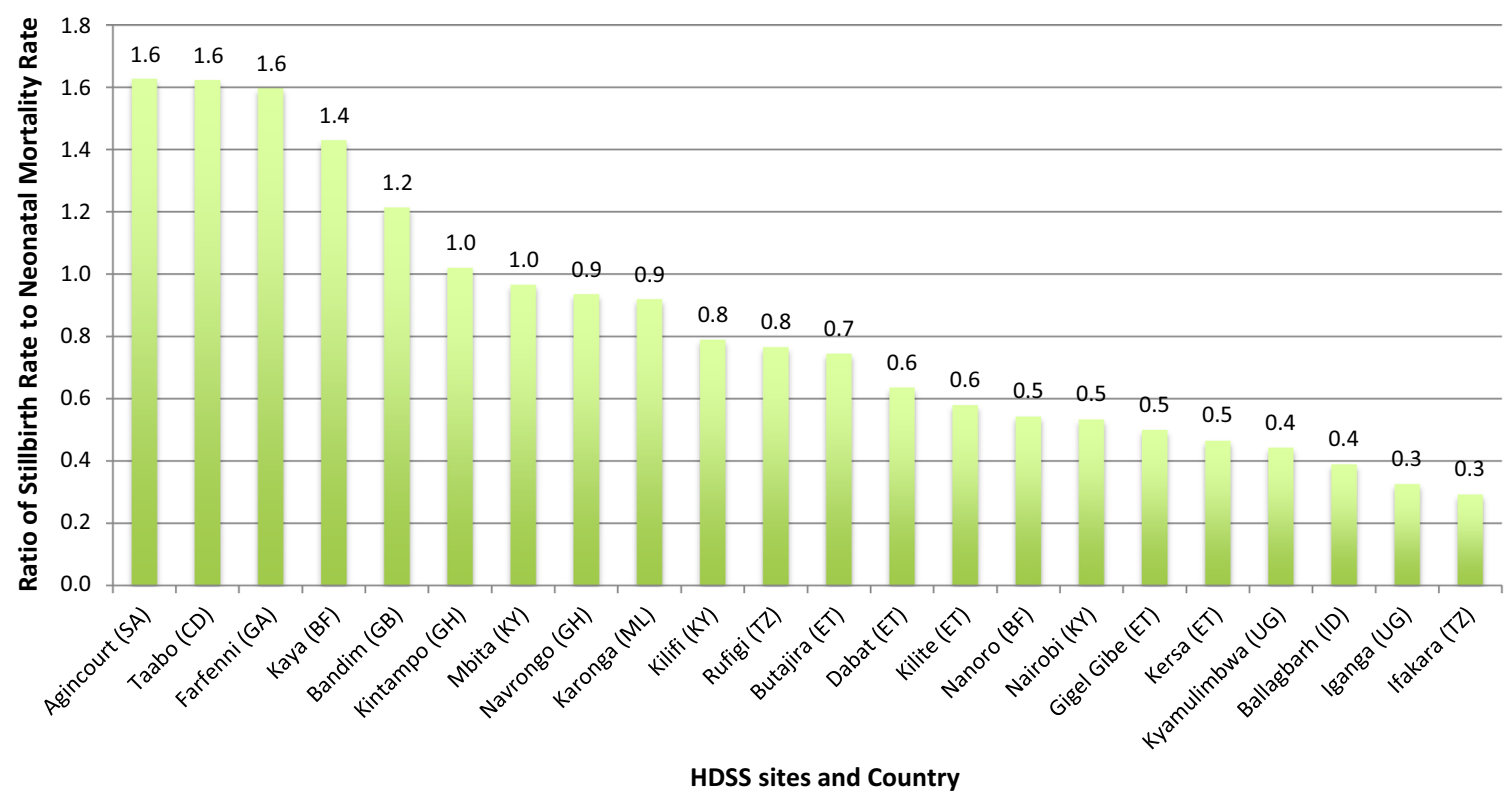

Fig. 1 Ratio of stillbirth rate to neonatal mortality rate across sites. Ratio of stillbirth rate to neonatal mortality rate from 22 Health and Demographic Surveillance Sites for the period 2009-2014 [Key: (SA) — South Africa; (CD)—Côte d'Ivoire; (GA) — Gambia; (BF)—
Burkina Faso; (GB)—Guinea-Bissau; (KY)—Kenya; (GH)—Ghana; (ML)_Malawi; (TZ)_Tanzania; (ET)_Ethiopia; (UG)_Uganda; (ID)_-India] 


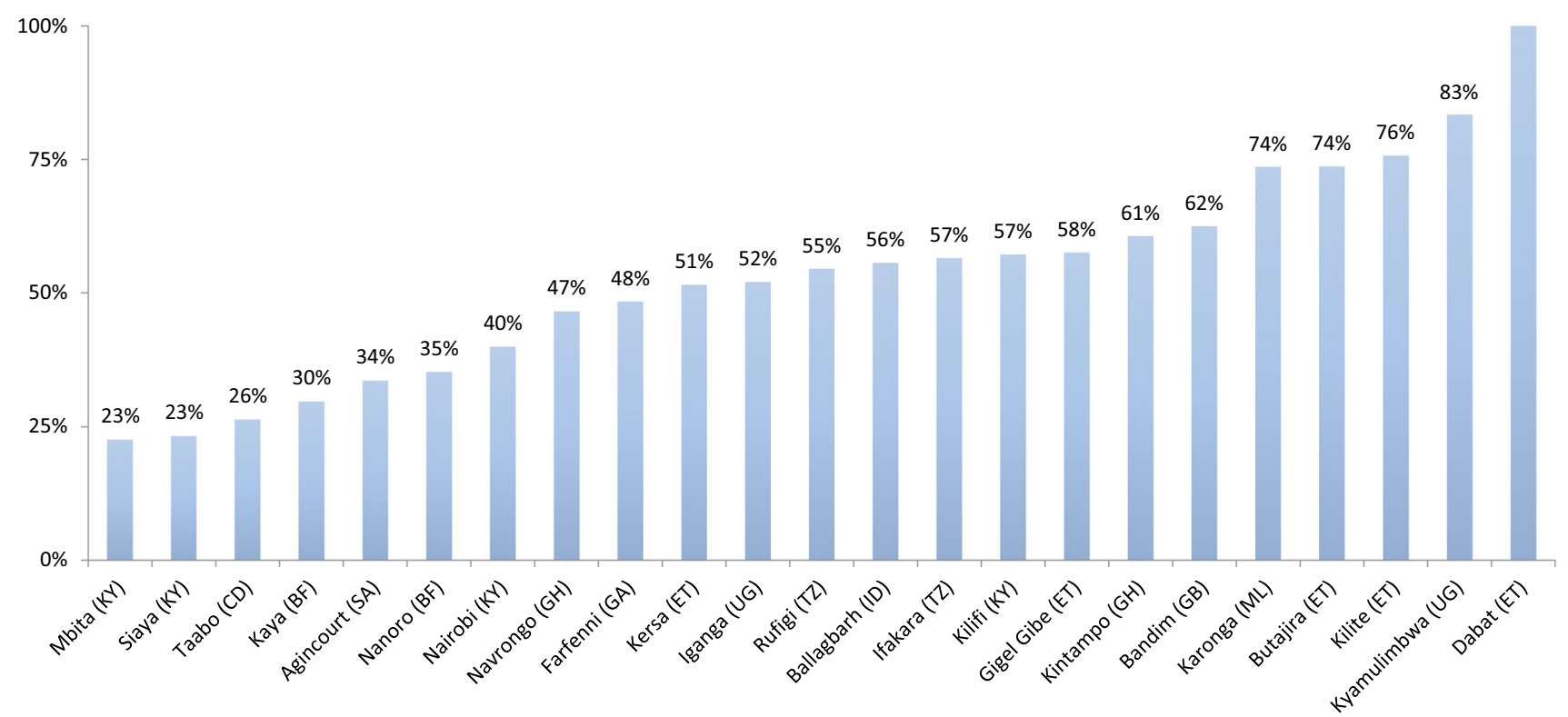

Fig. 2 Proportion of infant deaths (first year) that occur in the neonatal period (first month) across sites. Proportion of infant deaths that are neonatal deaths from 22 Health and Demographic Surveillance Sites for the period 2009-2014 [Key: (SA)—South Africa;

Surveys and WHO-generated estimates for national mortality rates. Good quality data generated from sites can be helpful in strengthening and testing the quality of other mortality data sources. Sites with more frequent surveillance rounds, for example twice or thrice a year, and those that directed questions to women of childbearing age in the household, rather than just the household head, had SBR and NMR in a plausible range, which were also closer to regional and national estimates.

\section{Discussion}

INDEPTH Network sites have potential for addressing key data, innovation and programme monitoring needs, especially with regard to the ENAP, the UN Strategy for Women and Children, the EPMMD strategy, key components of the SDG agenda, as well as to the emerging field of pregnancy- and childhood-related pharmacovigilance. However, we found a wide range of stillbirth and neonatal mortality rates across the different sites, suggesting huge variations in site capacities for measuring birth outcomes. The different methods for capturing pregnancy and birth outcome data across sites are likely to contribute to underreporting of events that occur around the time of birth. The findings suggest that in many sites, pregnancies and negative pregnancy outcomes are missing. These variations are likely due to limited site focus and capacity on maternal and newborn research and/or reflect difficulties in measuring these events.
(CD)—Côte d'Ivoire; (GA) — Gambia; (BF)—Burkina Faso; (GB)— Guinea-Bissau; (KY)-Kenya; (GH)_Ghana; (ML)-Malawi; (TZ)_Tanzania; (ET)—Ethiopia; (UG)—Uganda; (ID)_India]

Based on the international literature, the expected ratio of stillbirths to neonatal deaths is around 1 . However, we found that in these settings, the median ratio of SBR to NMR was 0.8 , but three sites had a ratio of SBR to NMR of $\leq 0.3$, likely representing substantial underrecording of stillbirths compared to neonatal deaths (Blencowe et al. 2016). Importantly, the definition of stillbirth was consistent across sites and consistent with the World Health Organization definition for international comparison of a death at a birthweight of $1000 \mathrm{~g}$ or more, if the birthweight is not available, a gestational age of 28 weeks or more or a length of $35 \mathrm{~cm}$ or more. However, the majority of the sites rely on a woman's recall of her last menstrual period to determine gestational age, which may not be accurate, and most stillbirths are not weighed at birth. Innovative methods are urgently needed to ensure that every pregnancy outcome is measured in terms of birthweight. Generally, stillbirths are more poorly recorded than newborn deaths. However, there may be underrecording for both stillbirths and neonatal deaths in some of the HDSS sites. The two sites with the highest ratio of stillbirths to neonatal deaths were located in South Africa, which may be plausible given the increased access to health services that are succeeding at reducing deaths among live born neonates.

With regard to neonatal mortality, sites reported rates from less than 10 per 1000 live births to 41.6 deaths per live births. Such a range is indicative of problems in data capture. Similarly, sites reporting on neonatal mortality indicated that only $1.3 \%$ of all neonatal deaths occurred on the first day, which is counter to common understanding 
Table 2 Characteristics of surveillance systems

\begin{tabular}{|c|c|c|c|c|c|c|}
\hline HDSS name & Country & $\begin{array}{l}\text { Frequency of } \\
\text { rounds }\end{array}$ & $\begin{array}{l}\text { Information } \\
\text { collected relevant } \\
\text { to birth outcomes }\end{array}$ & Data collector & Acceptable respondent & Other information \\
\hline Africa Centre & $\begin{array}{l}\text { South } \\
\text { Africa }\end{array}$ & $\begin{array}{l}\text { Three update } \\
\text { rounds a year }\end{array}$ & $\begin{array}{l}\text { All births, deaths, } \\
\text { marriages and } \\
\text { migrations, } \\
\text { socio-economics, } \\
\text { biometrics, HIV } \\
\text { status and sexual } \\
\text { behaviour }\end{array}$ & & $\begin{array}{l}\text { Senior household } \\
\text { member }\end{array}$ & $\begin{array}{l}\text { The data are stored in a single } \\
\text { Microsoft SQL server } \\
\text { database }\end{array}$ \\
\hline Agincourt & $\begin{array}{l}\text { South } \\
\text { Africa }\end{array}$ & One annual round & $\begin{array}{l}\text { Migration, death, } \\
\text { maternal history, } \\
\text { pregnancy and } \\
\text { outcome } \\
\text { surveillance }\end{array}$ & $\begin{array}{l}\text { Four teams, one } \\
\text { supervisor, eight } \\
\text { fieldworkers }\end{array}$ & $\begin{array}{l}\text { Household head, spouse } \\
\text { or adult member in the } \\
\text { house }\end{array}$ & $\begin{array}{l}\text { The database is managed } \\
\text { using Microsoft SQL } \\
\text { servers }\end{array}$ \\
\hline Ballabgarh & India & $\begin{array}{l}\text { (Monthly) } \\
\text { Pregnancy, } \\
\text { gestational age, } \\
\text { stillbirth } \\
\text { outcomes and } \\
\text { birthweight }\end{array}$ & $\begin{array}{l}\text { Migration, } \\
\text { antenatal care, } \\
\text { immunization, } \\
\text { family planning, } \\
\text { morbidity and } \\
\text { verbal autopsy }\end{array}$ & & & $\begin{array}{l}\text { The database is handled in } \\
\text { DBASE III and Microsoft } \\
\text { SQL }\end{array}$ \\
\hline Bandim & $\begin{array}{l}\text { Guinea- } \\
\text { Bissau }\end{array}$ & $\begin{array}{l}\text { Monthly in the } \\
\text { urban site and } \\
\text { biannually in the } \\
\text { rural site }\end{array}$ & $\begin{array}{l}\text { Vaccination and } \\
\text { vitamin A } \\
\text { supplementation }\end{array}$ & Fieldworkers & & \\
\hline Butajira & Ethiopia & $\begin{array}{l}\text { (Quarterly) } \\
\text { pregnancy } \\
\text { surveillance: each } \\
\text { household has } \\
\text { been visited once } \\
\text { per month from } \\
1987 \text { to } 1999 \text { and } \\
\text { four times in year } \\
\text { since } 1999\end{array}$ & $\begin{array}{l}\text { Child health, } \\
\text { mortality } \\
\text { patterns, health } \\
\text { systems and } \\
\text { financing, verbal } \\
\text { autopsy, malaria, } \\
\text { nutrition status } \\
\text { and domestic } \\
\text { violence }\end{array}$ & $\begin{array}{l}21 \text { Data collectors } \\
\text { and } 7 \\
\text { supervisors, } 2 \\
\text { field coordinators }\end{array}$ & $\begin{array}{l}\text { Household head/spouse } \\
\text { and adult member of } \\
\text { the family }\end{array}$ & $\begin{array}{l}\text { The data are entered into the } \\
\text { Household Registration } \\
\text { System } 2 \text { (HRS2) and } \\
\text { stored on the FoxPro server }\end{array}$ \\
\hline Dabat & Ethiopia & $\begin{array}{l}\text { (Biannually) } \\
\text { pregnancy, } \\
\text { gestational age, } \\
\text { delivery and } \\
\text { stillbirth } \\
\text { outcomes }\end{array}$ & $\begin{array}{l}\text { Births, verbal } \\
\text { autopsy, } \\
\text { migrations, } \\
\text { pregnancies and } \\
\text { pregnancy } \\
\text { outcomes }\end{array}$ & & $\begin{array}{l}\text { Adult women or } \\
\text { Mothers of the } \\
\text { households }\end{array}$ & $\begin{array}{l}\text { Data are collected on paper } \\
\text { and entered using Dabat } \\
\text { database Household } \\
\text { Registration System } 2\end{array}$ \\
\hline Dodowa & Ghana & $\begin{array}{l}\text { (Biannually) } \\
\text { pregnancy, } \\
\text { delivery, stillbirth } \\
\text { outcomes, } \\
\text { birthweight }\end{array}$ & $\begin{array}{l}\text { Verbal autopsy, } \\
\text { migration and } \\
\text { pregnancy, } \\
\text { spatial data and } \\
\text { outcome } \\
\text { surveillance }\end{array}$ & & & $\begin{array}{l}\text { The data are entered into the } \\
\text { Household Registration } \\
\text { System } 2 \text { and store on the } \\
\text { Microsoft SQL server }\end{array}$ \\
\hline Farfenni & Gambia & $\begin{array}{l}\text { (Quarterly) } \\
\text { pregnancy, } \\
\text { birthweight and } \\
\text { neonatal } \\
\text { morbidity }\end{array}$ & $\begin{array}{l}\text { Verbal autopsy, } \\
\text { vaccination, } \\
\text { migration, } \\
\text { pregnancy } \\
\text { registration and } \\
\text { outcome and } \\
\text { spatial data }\end{array}$ & & & $\begin{array}{l}\text { The data are entered into the } \\
\text { Household Registration } \\
\text { System } 2 \text { and store on the } \\
\text { Microsoft SQL server }\end{array}$ \\
\hline Gilgel Gibe & Ethiopia & $\begin{array}{l}\text { Biannual } \\
\text { population } \\
\text { update, } \\
\text { pregnancy } \\
\text { outcome, death, } \\
\text { migration, martial } \\
\text { change among } \\
\text { women, } \\
\text { pregnancy } \\
\text { observation. } \\
\text { Yearly updates } \\
\text { for education, } \\
\text { marital status and } \\
\text { occupation }\end{array}$ & $\begin{array}{l}\text { Maternal and child } \\
\text { health, verbal } \\
\text { autopsy }\end{array}$ & $\begin{array}{l}\text { Men and women } \\
\text { who completed at } \\
\text { least secondary } \\
\text { education }\end{array}$ & $\begin{array}{l}\text { Household head, spouse } \\
\text { or adult member in the } \\
\text { house }\end{array}$ & $\begin{array}{l}\text { Household Registration } \\
\text { System } 2 \text { database is used } \\
\text { for data entry. Data are } \\
\text { collection is paper-based } \\
\text { and planned to be migrated } \\
\text { to OpenHDSS. The HDSS } \\
\text { site is owned and run by } \\
\text { Jimma University }\end{array}$ \\
\hline
\end{tabular}


Table 2 (continued)

\begin{tabular}{|c|c|c|c|c|c|c|}
\hline HDSS name & Country & $\begin{array}{l}\text { Frequency of } \\
\text { rounds }\end{array}$ & $\begin{array}{l}\text { Information } \\
\text { collected relevant } \\
\text { to birth outcomes }\end{array}$ & Data collector & Acceptable respondent & Other information \\
\hline Ifakara & Tanzania & $\begin{array}{l}\text { Three update } \\
\text { rounds a year. } \\
\text { With four months } \\
\text { for each round } \\
\text { starting at } \\
\text { January, May and } \\
\text { September }\end{array}$ & $\begin{array}{l}\text { Pregnancies, births } \\
\text { deaths }\end{array}$ & & & \\
\hline $\begin{array}{l}\text { Iganga- } \\
\text { Mayuge }\end{array}$ & Uganda & $\begin{array}{l}\text { Two update rounds } \\
\text { per year with a } \\
\text { round lasting } \\
\text { about } 2-3 \text { months }\end{array}$ & $\begin{array}{l}\text { Births, deaths, } \\
\text { migrations, } \\
\text { pregnancy } \\
\text { registration and } \\
\text { outcome } \\
\text { surveillance, } \\
\text { vaccination, } \\
\text { socio-economic } \\
\text { characteristics } \\
\text { and verbal } \\
\text { autopsy }\end{array}$ & $\begin{array}{l}\text { Research } \\
\text { assistants, scouts, } \\
\text { Village Health } \\
\text { Teams (VHT) } \\
\text { members }\end{array}$ & $\begin{array}{l}\text { Adult member of the } \\
\text { household }\end{array}$ & $\begin{array}{l}\text { The data are collected using } \\
\text { paper-based system and is } \\
\text { entered into the Household } \\
\text { Registration System } 2 \text { and } \\
\text { stored on the MySQL } \\
\text { server. The site will migrate } \\
\text { to OpenHDSS in } 2017\end{array}$ \\
\hline Karonga & Malawi & $\begin{array}{l}\text { Births and deaths } \\
\text { are reported } \\
\text { monthly and in- } \\
\text { and-out migration } \\
\text { is collected } \\
\text { annually }\end{array}$ & $\begin{array}{l}\text { Migration, } \\
\text { vaccination, } \\
\text { verbal autopsy }\end{array}$ & Fieldworkers & $\begin{array}{l}\text { Local "key informants" } \\
\text { who may not be a } \\
\text { member of that } \\
\text { household or } \\
\text { household member }\end{array}$ & $\begin{array}{l}\text { Data are collected on paper } \\
\text { and I entered into a MS } \\
\text { Access database }\end{array}$ \\
\hline Kaya & $\begin{array}{l}\text { Burkina } \\
\text { Faso }\end{array}$ & $\begin{array}{l}\text { (Biannually) } \\
\text { pregnancy and } \\
\text { stillbirth } \\
\text { outcomes }\end{array}$ & $\begin{array}{l}\text { Births, verbal } \\
\text { autopsy, } \\
\text { marriage, } \\
\text { migration, } \\
\text { pregnancies and } \\
\text { morbidity }\end{array}$ & & $\begin{array}{l}\text { Member of the } \\
\text { household }\end{array}$ & $\begin{array}{l}\text { Data are collected using } \\
\text { personal digital assistants } \\
\text { using the CSPro software } \\
\text { and is saved on the } \\
\text { MySQL-PHP database }\end{array}$ \\
\hline Kersa & Ethiopia & $\begin{array}{l}\text { (Quarterly) } \\
\text { Pregnancy, } \\
\text { gestational age, } \\
\text { delivery, stillbirth } \\
\text { outcomes, } \\
\text { birthweight } \\
\text { information, } \\
\text { neonatal and } \\
\text { under-five } \\
\text { morbidity } \\
\text { surveillance }\end{array}$ & $\begin{array}{l}\text { Maternal and child } \\
\text { health and verbal } \\
\text { autopsy }\end{array}$ & & $\begin{array}{l}\text { Preferably head of the } \\
\text { household, mother, if } \\
\text { not children in the } \\
\text { house who are older } \\
\text { than } 15 \text { years }\end{array}$ & $\begin{array}{l}\text { Data are collected using } \\
\text { paper, consistency and } \\
\text { completeness check is done } \\
\text { by resident supervisors and } \\
\text { field coordinators. Once } \\
\text { completed entered in HRS } \\
2 \text { software and Hardcopy } \\
\text { archived }\end{array}$ \\
\hline Kilifi & Kenya & $\begin{array}{l}\text { (Three times per } \\
\text { year) pregnancy, } \\
\text { delivery, stillbirth } \\
\text { outcomes, } \\
\text { maternal } \\
\text { outcomes }\end{array}$ & $\begin{array}{l}\text { Migration, verbal } \\
\text { autopsy, births, } \\
\text { pregnancy } \\
\text { surveillance and } \\
\text { vaccination }\end{array}$ & & & $\begin{array}{l}\text { The data are managed in a } \\
\text { central server database } \\
\text { which is specified in } \\
\text { FileMaker Pro version } 11\end{array}$ \\
\hline $\begin{array}{l}\text { Kilte } \\
\text { Awulaelo }\end{array}$ & Ethiopia & $\begin{array}{l}\text { (Biannually) } \\
\text { Pregnancy, } \\
\text { gestational age, } \\
\text { delivery and } \\
\text { stillbirth } \\
\text { outcomes }\end{array}$ & & & & \\
\hline Kintampo & Ghana & $\begin{array}{l}\text { (Biannually) } \\
\text { pregnancy and } \\
\text { stillbirth } \\
\text { outcomes }\end{array}$ & $\begin{array}{l}\text { Micronutrient } \\
\text { initiatives }\end{array}$ & & & \\
\hline Kombewa & Kenya & $\begin{array}{l}\text { Demographic } \\
\text { updates and } \\
\text { surveillance is } \\
\text { done twice a year } \\
\text { (births, deaths } \\
\text { and pregnancy } \\
\text { outcomes) }\end{array}$ & $\begin{array}{l}\text { Birth registration, } \\
\text { verbal autopsy, } \\
\text { migration, } \\
\text { pregnancy } \\
\text { surveillance and } \\
\text { morbidity }\end{array}$ & $\begin{array}{l}\text { Village team } \\
\text { reporters }\end{array}$ & & $\begin{array}{l}\text { Electronic data collection } \\
\text { with PDAs/notebook PCs } \\
\text { and the data are stored in } \\
\text { the MySQL database }\end{array}$ \\
\hline
\end{tabular}


Table 2 (continued)

\begin{tabular}{|c|c|c|c|c|c|c|}
\hline HDSS name & Country & $\begin{array}{l}\text { Frequency of } \\
\text { rounds }\end{array}$ & $\begin{array}{l}\text { Information } \\
\text { collected relevant } \\
\text { to birth outcomes }\end{array}$ & Data collector & Acceptable respondent & Other information \\
\hline Kyamulimbwa & Uganda & $\begin{array}{l}\text { Annual census, } \\
\text { supplemented by } \\
\text { real-time } \\
\text { reporting from } \\
\text { village health } \\
\text { workers }\end{array}$ & $\begin{array}{l}\text { Pregnancy and } \\
\text { outcomes, births } \\
\text { and deaths }\end{array}$ & $\begin{array}{l}\text { Census team, } \\
\text { village recorders }\end{array}$ & $\begin{array}{l}\text { Either the head of } \\
\text { household or women } \\
\text { of reproductive age }\end{array}$ & $\begin{array}{l}\text { Data are collected directly } \\
\text { onto ultra-mobile personal } \\
\text { computers. Pregnancy } \\
\text { registration using mobile } \\
\text { phone app (DoForm) by } \\
\text { village health workers }\end{array}$ \\
\hline Mbita & Kenya & $\begin{array}{l}\text { Every } 3 \text { months in } \\
\text { Mbita and } \\
4 \text { months in } \\
\text { Kwale }\end{array}$ & $\begin{array}{l}\text { Vaccination, } \\
\text { nutritional status } \\
\text { of children, } \\
\text { pregnancy } \\
\text { surveillance } \\
\text { (update } \\
\text { pregnancy status, } \\
\text { outcome, } \\
\text { antenatal care } \\
\text { and place of } \\
\text { deliver), } \\
\text { migration }\end{array}$ & & & $\begin{array}{l}\text { Electronic data collection } \\
\text { with PDAs and the data are } \\
\text { stored in the MySQL } \\
\text { database }\end{array}$ \\
\hline Nairobi & Kenya & Every 4 months & $\begin{array}{l}\text { Pregnancy } \\
\text { registration, } \\
\text { verbal autopsy } \\
\text { pregnancy } \\
\text { outcomes, } \\
\text { migrations, } \\
\text { spatial data and } \\
\text { vaccines }\end{array}$ & $\begin{array}{l}\text { Team of trained } \\
\text { fieldworkers } \\
\text { from the HDSS } \\
\text { area with a } \\
\text { minimal of O } \\
\text { level certificate } \\
\text { of education. } \\
\text { VAs are } \\
\text { conducted by } \\
\text { team supervisors } \\
\text { with a minimum } \\
\text { of Bachelor's } \\
\text { degree in Social } \\
\text { sciences }\end{array}$ & $\begin{array}{l}\text { Household head or other } \\
\text { adult member of } \\
\text { household }\end{array}$ & $\begin{array}{l}\text { Data were collected using } \\
\text { paper questionnaires until } \\
\text { June } 2015 \text {. Electronic data } \\
\text { collection since July } 2015\end{array}$ \\
\hline Nanoro & $\begin{array}{l}\text { Burkina } \\
\text { Faso }\end{array}$ & $\begin{array}{l}\text { Three times a year } \\
\text { (every four } \\
\text { months) follow- } \\
\text { up surveys are } \\
\text { conducted }\end{array}$ & $\begin{array}{l}\text { Births, verbal } \\
\text { autopsy } \\
\text { migrations, } \\
\text { pregnancies and } \\
\text { pregnancy } \\
\text { outcomes, } \\
\text { vaccination, } \\
\text { socio-economic } \\
\text { characteristics } \\
\text { and verbal } \\
\text { autopsy }\end{array}$ & & & $\begin{array}{l}\text { Data are collected on paper } \\
\text { and entered in the } \\
\text { Household Registration } \\
\text { System } 2\end{array}$ \\
\hline Navrongo & Ghana & $\begin{array}{l}\text { (Three times a } \\
\text { year) Pregnancy, } \\
\text { stillbirth } \\
\text { outcomes, } \\
\text { birthweight and } \\
\text { neonatal } \\
\text { morbidity }\end{array}$ & $\begin{array}{l}\text { Reproductive } \\
\text { health, } \\
\text { vaccination, } \\
\text { impact } \\
\text { assessment }\end{array}$ & & & \\
\hline Nouna & $\begin{array}{l}\text { Burkina } \\
\text { Faso }\end{array}$ & & & & & $\begin{array}{l}\text { Data are collected on pocket } \\
\text { PCs and stored on the SQL } \\
\text { server pro }\end{array}$ \\
\hline Ouagadougou & $\begin{array}{l}\text { Burkina } \\
\text { Faso }\end{array}$ & $\begin{array}{l}\text { One round every } \\
10 \text { months }\end{array}$ & $\begin{array}{l}\text { Pregnancy } \\
\text { registration, } \\
\text { deaths, } \\
\text { pregnancy } \\
\text { outcomes, } \\
\text { migrations, } \\
\text { spatial data and } \\
\text { vaccines }\end{array}$ & & $\begin{array}{l}\text { Adult member of the } \\
\text { household }\end{array}$ & $\begin{array}{l}\text { Data are collected on pocket } \\
\text { PCs and stored on the } \\
\text { MySQL server pro }\end{array}$ \\
\hline Puworejo & Indonesia & & $\begin{array}{l}\text { Reproductive } \\
\text { health and verbal } \\
\text { autopsy }\end{array}$ & & & \\
\hline
\end{tabular}


Table 2 (continued)

\begin{tabular}{|c|c|c|c|c|c|c|}
\hline HDSS name & Country & $\begin{array}{l}\text { Frequency of } \\
\text { rounds }\end{array}$ & $\begin{array}{l}\text { Information } \\
\text { collected relevant } \\
\text { to birth outcomes }\end{array}$ & Data collector & Acceptable respondent & Other information \\
\hline Rakai & Uganda & $\begin{array}{l}\text { (Started 2015) } \\
\text { Pregnancy } \\
\text { surveillance and } \\
\text { stillbirth } \\
\text { outcomes }\end{array}$ & $\begin{array}{l}\text { Pregnancy and } \\
\text { outcome } \\
\text { surveillance, } \\
\text { verbal autopsy, } \\
\text { migration (of the } \\
\text { mother), HIV } \\
\text { status and HIV } \\
\text { care of the } \\
\text { mother, birth } \\
\text { history } \\
\text { information } \\
\text { (including family } \\
\text { planning use) and } \\
\text { socio-economic } \\
\text { status }\end{array}$ & $\begin{array}{l}\text { Research } \\
\text { assistantsN (2015 }\end{array}$ & $\begin{array}{l}\text { 1. Migration and socio- } \\
\text { economic status: any } \\
\text { eligible household } \\
\text { member } 2 \text {. Verbal } \\
\text { autopsy: any closest } \\
\text { caregiver } 3 \text {. } \\
\text { Pregnancy outcomes, } \\
\text { birth history, HIV } \\
\text { status: the woman }\end{array}$ & $\begin{array}{l}\text { Electronic data collection } \\
\text { using laptops and stored in } \\
\text { SQL database }\end{array}$ \\
\hline Rufiji & Tanzania & $\begin{array}{l}\text { (Three times a } \\
\text { year) Pregnancy, } \\
\text { stillbirth } \\
\text { outcomes, } \\
\text { birthweight and } \\
\text { neonatal } \\
\text { morbidity and } \\
\text { maternal deaths }\end{array}$ & $\begin{array}{l}\text { Pregnancy and } \\
\text { outcome } \\
\text { surveillance, } \\
\text { verbal autopsy, } \\
\text { migration and } \\
\text { socio-economic } \\
\text { status }\end{array}$ & & & $\begin{array}{l}\text { Site uses OpenHDSS } \\
\text { platform as the database } \\
\text { since } 2012\end{array}$ \\
\hline Siaya & Kenya & $\begin{array}{l}\text { (Three times a } \\
\text { year) Pregnancy } \\
\text { outcomes, } \\
\text { birthweight and } \\
\text { neonatal } \\
\text { morbidity and } \\
\text { maternal deaths }\end{array}$ & $\begin{array}{l}\text { Migration, verbal } \\
\text { autopsy and } \\
\text { pregnancy } \\
\text { surveillance }\end{array}$ & & & $\begin{array}{l}\text { Electronic data collection } \\
\text { with PDAs/Notebook PCs } \\
\text { using the mobile Household } \\
\text { Registration System and } \\
\text { stored on the MySQL } \\
\text { database }\end{array}$ \\
\hline Taabo & $\begin{array}{l}\text { Côte } \\
\text { d'Ivoire }\end{array}$ & $\begin{array}{l}\text { Three times a year } \\
\text { (every four } \\
\text { months }\end{array}$ & $\begin{array}{l}\text { Births, pregnancies } \\
\text { (probable date of } \\
\text { conception, } \\
\text { gestational age, } \\
\text { course of } \\
\text { pregnancy), } \\
\text { migrations, } \\
\text { epidemiology } \\
\text { and verbal } \\
\text { autopsy }\end{array}$ & $\begin{array}{l}12 \text { Permanent } \\
\text { enumerators and } \\
6 \text { supervisors }\end{array}$ & $\begin{array}{l}\text { Adult member of } \\
\text { household }\end{array}$ & $\begin{array}{l}\text { The data are entered into the } \\
\text { Household Registration } \\
\text { System } 2 \text { and store on the } \\
\text { MySQL server }\end{array}$ \\
\hline Vadu & India & $\begin{array}{l}\text { Biannually, births, } \\
\text { deaths, } \\
\text { marriages, } \\
\text { migrations and } \\
\text { pregnancy. Every } \\
\text { reported death is } \\
\text { subjected to a } \\
\text { verbal autopsy }\end{array}$ & $\begin{array}{l}\text { Reproductive } \\
\text { health, } \\
\text { telemedicine, } \\
\text { spatial data and } \\
\text { verbal autopsy }\end{array}$ & $\begin{array}{l}12 \text { Field research } \\
\text { assistants }\end{array}$ & $\begin{array}{l}\text { Adult member of the } \\
\text { household who can } \\
\text { give information }\end{array}$ & $\begin{array}{l}\text { Electronic data capture on } \\
\text { tablets using android } \\
\text { application }\end{array}$ \\
\hline
\end{tabular}

The characteristics of the surveillance systems of the 31 Health and Demographic Surveillance Sites located in 13 countries for the period (2009-2014)

that $75 \%$ of deaths occur in the first week, with 40 per cent in the first day after birth (Engmann et al. 2012; WHO 2011). In addition, the proportion of deaths in the first year attributed to neonatal deaths ranged from $22.6 \%$ (which likely means underreporting of neonatal events) to $100 \%$ (suggesting an absence of accurate capture of infant mortality, which is typically twice the neonatal mortality rate). We also found that the neonatal mortality rates in the
HDSS were lower than the national average for the country in most sites. Several reasons could explain this, including possible underreporting by HDSS sites, differences in methods of measurement or actual lower mortality in HDSS sites due to increased services and monitoring over many years. The HDSS site populations are generally in small defined areas which are often subject to interventions or routine measurements, undertakings which can be 
associated with mortality reduction, and hence lower rates. However, whereas actual NMR could be lower, we do think that the quality of surveillance in HDSS sites around the time of birth is a major contributor. For instance, we found that the type of surveillance system used by sites mattered. We recommend that surveys be more frequent (e.g. 2-3 times a year) and they should target women of childbearing age themselves as the respondents, not other heads of households.

On the other hand, sites which registered pregnancies upon locating a live baby in the routine household surveillance round ("pregnancy at birth") tended to have lower recorded mortality rates compared to those that assessed neonatal deaths by registered pregnancy. This suggests that some of the options for improving capture of events around pregnancy in HDSS sites could include shorter recall periods (more rounds), having women of childbearing age as respondents and improving pregnancy registration and surveillance for outcomes. However, it should be noted that these options are more logistically intense and expensive. In addition, by interviewing only women of childbearing age, we are likely to miss a few pregnancy outcomes in cases of a maternal death, which is itself known to be associated with the death of a baby. The finding that in some sites stillbirth and NMR were lower than national averages could suggest that either HDSS sites underestimate these events or national surveys such as DHS could be overestimating such events. National estimates-often calculated through modelling exercises based upon small samples of relatively rare events-are derived from methods that are, in general, more susceptible to bias, particularly recall bias and biases associated with the taboo of discussing bad events.

The need to improve surveillance for pregnancy and outcomes in HDSS sites has recently been emphasized (Lawn et al. 2014; Moxon et al. 2015), and our findings corroborate this recommendation. Better surveillance could play a major role in addressing the SDG measurement agenda, especially that related to the ENAP and the EPMM plans, particularly since most HDSS sites are located in countries with the highest burden of stillbirths and neonatal mortality. The presence of several HDSS sites in a country or region allows for country and regional comparisons, and the richness of high-quality HDSS data can contribute to equity analyses and information on background characteristics and risk factors contributing to mortality. The prospective nature of HDSS data and availability of cause of death data also allow for better programme targeting over time, as the mortality share of different diseases can change. Improving pregnancy and outcome surveillance will also provide INDEPTH with a platform to monitor scale-up and safety of new and old interventions such as immunization and medicines taken during pregnancy, and any unintended consequences such as birth defects. As such, HDSS data can be a powerful precision public health tool to inform programming, advocacy and testing new innovations.

For HDSS sites to achieve their full potential, however, data quality needs to be prioritized throughout the network. There is a need to standardize pregnancy and outcome data collection tools, indicator definition and analyses. This includes causes of death which were not included in this analysis but merit discussion. Current analyses of verbal autopsy data in INDEPTH HDSS use ICD-10 rules and do not group deaths into programmatically relevant categories as has been done by the Child Health Epidemiology Reference Group and others (Lawn et al. 2006, 2014; Liu et al. 2014; Lozano et al. 2012; Wang et al. 2014). For instance, several studies have shown the growing importance of prematurity as a cause of death and disability and it is now the leading cause of under-five deaths worldwide (Liu et al. 2014). However, in current analyses of cause of death data in HDSS sites, prematurity does not feature highly (Streatfield et al. 2014). The increasing recognition of the HDSS potential has seen them to become the leading centres for research on morbidity surveillance such as the CHESS/CHAMPS studies and the minimally invasive autopsy (MIA), which aim to generate more precise causes of morbidity and mortality.

Research implications include further work needed on pregnancy validation, stillbirth and neonatal measurement, and cause of death coding. Fortunately, through work in the ENAP measurement agenda, work has started within INDEPTH to validate current surveillance systems and ENAP indicators, improve surveillance of pregnancy and outcomes and develop more accurate neonatal and verbal autopsy cause of death algorithms. This work will lead to improved measurement and will also inform other survey systems such as DHS and the Multiple Indicator Cluster Surveys (MICS). In broader terms, the INDEPTH Network should strengthen its systems to be able to validate its potential to monitor almost all indicators for SDGs.

A major strength of this study is that it includes data from 31 sites, representing a wide range of settings and surveillance systems. However, the study has some important limitations. The data are reported here as presented to the MNCH_WG, although several efforts were made to validate the data by having meetings and returning queries to sites. Furthermore, despite attempts to standardize definitions, some outcome variables could have varied across sites. The national and regional comparisons should be used with caution because the methods for estimating the national rates from global estimates and/or demographic and health surveys are not comparable to the timing or methodology used in the HDSS. Sub-national mortality data for the same time period are not available for 
most of these sites, highlighting the importance of the HDSS sites in contributing to national data. Given the background characteristics of households and individuals available in the HDSS databases, there is a potential to further explore these explanatory variables in the context of birth outcomes and mortality rates. In addition, future analyses could describe how different factors across sites, such as length of operation, incentives and surveillance timing, contribute to trends in data capture, particularly for pregnancy outcomes.

\section{Conclusion}

Greater understanding of the high risk of death in the days around and immediately after birth can help HDSS researchers and funders prioritize learning around urgently needed interventions, with information shared with policy makers and healthcare providers for wider uptake. The rich information available across INDEPTH sites can help to contribute towards bridging knowledge and action gaps around the time of birth and the subsequent weeks. INDEPTH has an important role to play in ENAP and the broader global maternal, newborn, child health and adolescent agenda. It is also a critical platform in the testing of new medicines and vaccines, interventions and packages and the ability to provide long-term follow-up, especially for preterm and birth asphyxia outcomes.

Nonetheless, for this potential to be achieved, there is need for INDEPTH Network sites to improve data capture and intentionally focus on metrics for pregnancy and the time of birth, given the massive burden of deaths and morbidity. The underreporting of pregnancies and birth outcomes is a major issue which needs to be addressed in order to achieve the full potential of the network. While all HDSS centres track pregnancies and their outcomes, extra attention to ensuring complete collection as well as standardized data collection systems for birth outcomes is required, in order to advance the work around this crucial time period to prevent maternal deaths, stillbirths and neonatal deaths. To bridge these gaps, studies are underway to identify the best methods for capturing pregnancies and their outcomes. However, if these sites are to achieve their full potential in the SDG era, they will require strategic funding, innovations around measurement and capacity building and partnerships.

Acknowledgements The authors acknowledge the support of the representatives of the different Health and Demographic Surveillance Sites (HDSS) centres that participated in the International Network for the Demographic Evaluation of Populations and their Health (INDEPTH) Network (Maternal Newborn Child Health Working Group) MNCH workshops in Ho, Ghana, in July 2013 and in Kampala in June 2015, the INDEPTH Network's collaborators, core funders as well as the support of Save the Children and Children's
Investment Fund Foundation (CIFF) which assisted in funding the workshops and working group activities.

List of participants we would like acknowledge from the workshops in Ho.

1. Mr. Aristide Romaric Bado, Kaya HDSS, Burkina Faso. 2. Mr. Kazienga Adama, Nanoro HDSS, Burkina Faso. 3. Mr. Roch Modeste Millogo, Ouagadougou, Burkina Faso. 4. Dr. Abdramane Soura, Ouagadougou, Burkina Faso. 5. Dr. Mamadou Ouattara, Nouna HDSS, Burkina Faso. 6. Mr. Eric Diboulo, Nouna HDSS, Burkina Faso. 7. Dr. Adama Baguiya, Kaya HDSS, Burkina Faso. 8. Dr. Lukas Gnaman Adiossan, Taabo, Cote d'Ivoire. 9. Mr. Siaka Kone, Taabo, Cote d'Ivoire. 10. Mr. Fasil Tessema Woldeselassie, Gilgel Gibe, Ethiopia. 11. Mrs. Muluemebet Abera Wordofa, Gilgel Gibe, Ethiopia. 12. Prof. Albrecht Jahn, Heidelberg University, Germany. 13. Dr. Peter Erwin Meissner, Ulm University, Germany. 14. Dr. Gbenga Ayodele Kayode, UMC Utrecht/SPH Legon, Ghana. 15. Mr. Daniel Kwaku Azongo, Navrongo, Ghana. 16. Dr. Abraham Rexford Oduro, Navrongo, Ghana. 17. Mr. Paul Welaga, Navrongo, Ghana. 18. Mrs. Monica Puoma Lambon-Quayefio, Clark University, US, Ghana. 19. Dr. Samuel Bosomprah, University of Ghana, Legon, Ghana. 20. Mrs. Doris Sarpong, Dodowa, Ghana. 21. Ms. Elizabeth Awini, Dodowa, Ghana. 22. Mr. Henry Tagoe, University of Ghana, Legon, Ghana. 23. Dr. Ayaga Bawah, Columbia University/SPH, Ghana. 24. Dr. Alexander Manu, Kintampo, Ghana. 25. Mr. Obed Ernest Nettey, Kintampo, Ghana. 26. Ms. Baaba Johnson, INDEPTH Network, Ghana. 27. Dr. Kofi Baku, INDEPTH Board, Ghana. 28. Dr. Amabelia Rodrigues, Bandim, Guinea-Bissau. 29. Dr. Mohan Lal Bairwa, Ballabgarh, India. 30. Dr. Anand Shantaram Kawade, Vadu, India. 31. Dr. Rahul Srivastava, Ballabgarh, India. 32. Ms. Veena Muralidharan, Vadu, India. 33. Mr. Abdul Wahab, Purworejo, Indonesia. 34. Mr. Morris Ndemwa Mwangangi, Mbita, Kenya. 35. Mr. Martin Kavao Mutua, Nairobi, Kenya. 36. Mr. Mark Onyango Otiende, Kilifi, Kenya. 37. Dr. Janet Nyawira Oyieko, Kombewa, Kenya. 38. Dr. Frank Ouma Odhiambo, Kisumu, Kenya. 39. Mr. Sammy Khagayi, Kisumu, Kenya. 40. Mr. George Mochamah Kong'A, Kilifi, Kenya. 41. Dr. Godfrey Allan Otieno Muga, Kombewa, Kenya. 42. Dr. Orvalho Joaquim Augusto, Manhica, Mozambique. 43. Prof. Cheikh Mbacké, INDEPTH SAC/Consultant, Senegal. 44. Prof. Samuel Manda, South Africa MRC, South Africa. 45. Mrs. Mandy Maredza, Agincourt, South Africa. 46. Prof. Karen Joanne Hofman, Agincourt, South Africa. 47. Dr. James Ndirangu, Africa Centre, South Africa.

\section{Compliance with ethical standards}

Conflict of interest The authors declare that they have no conflict of interest.

Ethical approval All the Health and Demographic Surveillance Sites have ethical approval to collect surveillance data on maternal, newborn and child health. The respondents who provided the primary data were consented by the each of the HDSS's officers. The data submitted by all the 31 sites about their population are aggregated data, therefore, are anonymized and cannot be used to identify anyone. All the sites that were invited to workshops from which they agreed to participate by providing their aggregated data, review, contribute to the manuscript writing and development, and nominate two authors per site.

Open Access This article is distributed under the terms of the Creative Commons Attribution 4.0 International License (http://creative commons.org/licenses/by/4.0/), which permits unrestricted use, distribution, and reproduction in any medium, provided you give appropriate credit to the original author(s) and the source, provide a link to the Creative Commons license, and indicate if changes were made. 


\section{References}

Blencowe H, Cousens S, Jassir FB, Say L, Chou D, Mathers C et al (2016) National, regional, and worldwide estimates of stillbirth rates in 2015, with trends from 2000: a systematic analysis. Lancet Glob Health 4(2):e98-e108

de Bernis L, Kinney MV, Stones W, Ten Hoope-Bender P, Vivio D, Leisher SH et al (2016) Stillbirths: ending preventable deaths by 2030. Lancet 387(10019):703-716

Engmann C, Walega P, Aborigo RA, Adongo P, Moyer CA, Lavasani L et al (2012) Stillbirths and early neonatal mortality in rural Northern Ghana. Trop Med Int Health 17(3):272-282

Froen JF, Friberg IK, Lawn JE, Bhutta ZA, Pattinson RC, Allanson ER et al (2016) Stillbirths: progress and unfinished business. Lancet 387(10018):574-586

IGME U (2017) Levels and trends in child mortality. United Nations Inter-agency Group for Child Mortality Estimation (UN IGME)

INDEPTH Network. INDEPTH Network home page

Lawn JE, Wilczynska-Ketende K, Cousens SN (2006) Estimating the causes of 4 million neonatal deaths in the year 2000. Int $\mathbf{J}$ Epidemiol 35(3):706-718

Lawn JE, Blencowe H, Oza S, You D, Lee AC, Waiswa P et al (2014) Progress, priorities, and potential beyond survival. Lancet 384:189-205

Lawn JE, Blencowe H, Waiswa P, Amouzou A, Mathers C, Hogan D et al (2016) Stillbirths: rates, risk factors, and acceleration towards 2030. Lancet 387(10018):587-603

Liu L, Oza S, Hogan D, Perin J, Rudan I, Lawn JE et al (2014) Global, regional, and national causes of child mortality in 2000-2013, with projections to inform post-2015 priorities: an updated systematic analysis. Lancet 385:430-440

Lozano R, Naghavi M, Foreman K, Lim S, Shibuya K, Aboyans V et al (2012) Global and regional mortality from 235 causes of death for 20 age groups in 1990 and 2010: a systematic analysis for the Global Burden of Disease Study 2010. Lancet 380(9859):2095-2128
Moxon SG, Ruysen H, Kerber KJ, Amouzou A, Fournier S, Grove J et al (2015) Count every newborn; a measurement improvement roadmap for coverage data. BMC Pregnancy Childbirth 15(2):S8

Murray CJ, Vos T, Lozano R, Naghavi M, Flaxman AD, Michaud C et al (2012) Disability-adjusted life years (DALYs) for 291 diseases and injuries in 21 regions, 1990-2010: a systematic analysis for the Global Burden of Disease Study 2010. Lancet 380(9859):2197-2223

Oza S, Cousens SN, Lawn JE (2014) Estimation of daily risk of neonatal death, including the day of birth, in 186 countries in 2013: a vital-registration and modelling-based study. Lancet Glob Health 2(11):e635-e644

Sankoh O, Byass P (2012) The INDEPTH Network: filling vital gaps in global epidemiology. Int J Epidemiol 41(3):579-588. https:// doi.org/10.1093/ije/dys081

Shiffman J (2010) Issue attention in global health: the case of newborn survival. Lancet 375(9730):2045-2049

Streatfield PK, Khan WA, Bhuiya A, Hanifi SM, Alam N, Ouattara M et al (2014) Cause-specific childhood mortality in Africa and Asia: evidence from INDEPTH health and demographic surveillance system sites. Glob Health Action 7:25363

UN (2015) Sustainable Development Goal 3: Ensure healthy lives and promote well-being for all at all ages. Retrieved from http:// www.un.org/sustainabledevelopment/health/

UNICEF, UNICEF, BANK W, WHO, UN (2015) Levels and trends in child mortality

Wang H, Liddell CA, Coates MM, Mooney MD, Levitz CE, Schumacher AE et al (2014) Global, regional, and national levels of neonatal, infant, and under-5 mortality during 1990-2013: a systematic analysis for the Global Burden of Disease Study 2013. Lancet 384:957-979

WHO (2011) Newborn death and illness. Retrieved 4 May 2018, http://www.who.int/pmnch/media/press_materials/fs/fs_newborn dealth_illness/en/

Publisher's Note Springer Nature remains neutral with regard to jurisdictional claims in published maps and institutional affiliations. 